\title{
ZAGADNIENIE PRAW PODMIOTOWYCH NA STYKU PRAWA PRYWATNEGO I PUBLICZNEGO ROZWAŻANIA DE LEGE FERENDA NA PRZYKŁADZIE OPLAT NALEŻNYCH KOMORNIKOWI
}

I. Ustawa z 29 sierpnia 1997 r. o komornikach sądowych i egzekucji ${ }^{1}$ zawiera specjalny mechanizm umożliwiajacy miarkowanie wysokości opłat egzekucyjnych związanych z egzekucją świadczeń pieniężnych. Chodzi tutaj o art. 49 ust. 7-10. Na ich podstawie dłużnik w terminie 7 dni od dnia uzyskania informacji o ściagnięciu opłaty albo od dnia doręczenia postanowienia komornika w przedmiocie ustalenia kosztów egzekucji może wystapić do sądu z wnioskiem o obniżenie wysokości tej opłaty. Sąd może przychylić się do tego wniosku po uwzględnieniu w szczególności nakładu pracy komornika lub sytuacji majątkowej wnioskodawcy oraz wysokości jego dochodów. Analogicznej regulacji w ustawie o komornikach i egzekucji zabrakło jednak w odniesieniu do opłat egzekucyjnych związanych z egzekucją świadczeń niepieniężnych. Brak ten jest przedmiotem kontrowersji w środowisku prawniczym. Krytycznie na ten temat wypowiedział się m.in. Rzecznik Praw Obywatelskich, zdaniem którego można tu mówić o pewnej luce prawnej². Rzecznik podkreśla niekonsekwencję polskiego ustawodawcy, który bez jakiegokolwiek racjonalnego uzasadnienia różnicuje sytuację prawną dłużników w egzekucji świadczeń pieniężnych i niepieniężnych. W konsekwencji RPO dostrzega tutaj naruszenie zasady równości wobec prawa wyrażonej w art. 32 Konstytucji RP. Dlatego też postuluje niezwłoczną interwencję ustawodawcy celem umożliwienia miarkowania wysokości opłat egzekucyjnych także w przypadku egzekucji świadczeń niepieniężnych.

Brak stosownych przepisów dostrzegany jest zwłaszcza w odniesieniu do egzekucji polegającej na opróżnieniu lokalu z rzeczy lub osób. Jak stanowi art. 51 ust. 1 tej ustawy, komornik pobiera wówczas opłatę stałą w wysokości $40 \%$ przeciętnego wynagrodzenia miesięcznego, z tym że odrębną opłatę w tej wysokości pobiera się od każdej izby.

Krytyczne stanowisko RPO w stosunku do obecnego stanu prawnego jest wynikiem rozpatrzenia wielu skarg, jakie do niego adresuja eksmitowani dłużnicy zmuszeni do zapłaty tej opłaty egzekucyjnej zgodnie z podaną wyżej

1 T.jedn.: Dz. U. 2011, Nr 231, poz. 1376.

2 Pismo Rzecznika Praw Obywatelskich (RPO) z 11 maja 2011 r. do Ministra Sprawiedliwości (znak: RPO-656704-IV/10/BB). 
stawką. Ich rozżalenie wynika m.in. z faktu, że na wysokość owej opłaty w żaden sposób nie wpływa niezwłoczne opróżnienie lokalu po wezwaniu otrzymanym od komornika. W konsekwencji wzbudza to w nich poczucie głębokiej niesprawiedliwości i krzywdy. Podkreślają oni nieadekwatność wysokości opłaty wynikającej z postanowienia komornika do rzeczywistego nakładu jego pracy. W skrajnych przypadkach bywa tak, że opłata w kwocie kilku tysięcy złotych pobierana jest de facto za skierowanie do eksmitowanej ubogiej rodziny jednego pisma.

Należy zwrócić uwagę, że krytyczna ocena obecnego stanu prawnego w przedmiotowej materii zaprezentowana przez RPO znajduje także solidne oparcie w orzecznictwie TK, który w ostatnich latach kilkukrotnie zajmował się problematyką konstytucyjności zasad ustalania opłat egzekucyjnych, jakie pobiera komornik. Zdaniem TK ustawodawca, wprowadzając regulacje prawne dotyczace tych opłat, powinien się kierować dwiema zasadami. Pierwsza z nich nakazuje takie ustalanie ich wysokości i sposobu pobierania, by wystąpił efekt zmobilizowania dłużnika do dobrowolnego spełnienia świadczenia. Druga natomiast nakazuje ustawodawcy powiązać wysokość tej opłaty z realnym nakładem pracy komornika ${ }^{3}$.

Można więc uznać, że w związku z pobieraniem przez komorników kosztów postępowania egzekucyjnego niekiedy dochodzi do sytuacji cechującej się rozdźwiękiem między tzw. literą prawa a powszechnym poczuciem słuszności. Dlatego też pojawia się pytanie, czy w trakcie oczekiwania na ewentualna interwencję ustawodawcy, możliwe jest wskazanie w polskim systemie prawnym innej podstawy prawnej która niejako w zastępstwie pozwalałaby przynajmniej w najbardziej jaskrawych przypadkach dokonywać miarkowania wysokości opłat egzekucyjnych z powołaniem na szeroko pojętą słuszność. Jednym z wyznaczników bowiem prawidłowo skonstruowanego systemu prawnego jest możliwość odnalezienia w tym systemie instrumentów prawnych pozwalających taki rozdźwięk między tzw. litera prawa a słusznością usuwać.

Już prima facie narzuca się odpowiedź, że taka podstawa de lege lata niestety nie istnieje. Musiałaby bowiem obowiązywać wyraźna regulacja postulowana przez RPO na wzór art. 49 ust. 7-10 ustawy o komornikach sądowych i egzekucji.

Ponadto należy zwrócić uwagę, że sposób pobierania opłat przez komornika jest diametralnie różny w zależności od tego, czy chodzi o egzekucję zobowiązań pieniężnych, czy tė̇ niepieniężnych. W tym pierwszym przypadku komornik nie pobiera od wierzyciela w momencie wszczęcia postępowania opłaty ani zaliczki na poczet opłaty, lecz ściaga tę opłatę od dłużnika w ramach toczącego się postępowania egzekucyjnego (art. 49 ust. 1 ustawy o komornikach sądowych i egzekucji w związku z art. 770 k.p.c.). Z kolei gdy chodzi o egzekucję zobowiązań niepieniężnych, wierzyciel uiszcza opłatę stałą w momencie wszczęcia postępowania, a komornik kończąc to postępowanie, orzeka postanowieniem o jego kosztach. Zgodnie z zasadą odpowiedzialności dłużnika za koszty postępowania egzekucyjnego oraz zasadą zwrotu wierzycielowi kosz-

${ }^{3}$ Wyrok TK z 8 maja 2006 r., P 18/05, OTK ZU 2006, nr 5A, poz. 53; wyrok TK z 17 maja 2005 r., P 6/04, OTK ZU 2005, nr 5A, poz. 50. 
tów niezbędnych do celowego prowadzenia egzekucji w postanowieniu tym orzeka na rzecz wierzyciela od dłużnika zwrot poniesionych przez niego kosztów w celu wyegzekwowania świadczenia, w tym również zwrot kwoty, która wierzyciel uiścił tytułem opłaty egzekucyjnej. W konsekwencji koszty, którymi w swoim postanowieniu komornik obciąża dłużnika, są następnie w znacznej części zwracane wierzycielowi dla pokrycia jego wydatków na opłatę egzekucyjna. Jak zostało wyżej wskazane, wierzyciel ją uiścił wraz ze złożeniem wniosku o wszczęcie egzekucji. Opisany mechanizm uiszczania opłaty egzekucyjnej diametralnie różniący się od mechanizmu uiszczania opłaty w przypadku egzekucji zobowiązań pieniężnych w praktyce uniemożliwia de lege lata dokonanie jakiegokolwiek miarkowania tej opłaty.

II. Przedstawiony powyżej problem inspiruje jednak do podjęcia daleko szerszych rozważań na temat spójności systemu prawnego, a zwłaszcza sensowności podziału na prawo publiczne i prywatne.

Istotne znaczenie mają charakter prawny owej opłaty egzekucyjnej, a także status prawny komornika. Jak kilka razy podkreślił już SN, komornik jest funkcjonariuszem publicznym, a ustalana i pobierana przez niego opłata jest rodzajem daniny publicznoprawnej określonej w ustawie co do wysokości, trybu uiszczania i rozliczania, niezależnej od rzeczywistego nakładu pracy komornika lub jego woli ${ }^{4}$.

Przy okazji rozpatrywania zagadnienia możliwości, albo raczej braku możliwości de lege lata miarkowania wysokości opłat egzekucyjnych w egzekucji zobowiązań niepieniężnych, pojawia się kwestia dopuszczalności stosowania $\mathrm{w}$ sektorze publicznym naczelnych zasad prawa prywatnego odwołujacych się bezpośrednio lub pośrednio do szeroko pojętej słuszności. W omawianym przypadku mam na myśli przede wszystkim zasadę zakazującą nadużywania praw podmiotowych, której sztandarowym wyrazem jest art. 5 k.c. Abstrahując bowiem od publicznoprawnego statusu komornika, analizowany przypadek, gdy komornik domaga się niewspółmiernie wysokiej opłaty w stosunku do własnego nakładu pracy, uzasadniając to żądanie obowiąujaccymi przepisami, przywołuje na myśl niejako odruchowo właśnie zasadę zakazującą nadużywania przysługujących praw podmiotowych. Jeżeli dopuścilibyśmy stosowanie tej zasady w sektorze publicznym niezależnie od kwalifikacji danych instytucji jako publicznoprawnych czy prywatnoprawnych, to podstawą obrony dłuźnika, przynajmniej w najbardziej jaskrawych przypadkach, przed żądaniem komornika wyrażonym w wydanym przez niego postanowieniu o kosztach postępowania egzekucyjnego mogłaby być naczelna zasada zakazujacca nadużywania praw podmiotowych. To prawda, że odwoływanie się do tej zasady w przypadku egzekucji zobowiązań pieniężnych nie jest potrzebne ze względu na ustawo wprowadzoną możliwość miarkowania wysokości opłat, natomiast ze względu na opisany mechanizm pobierania opłaty w egzekucji zobowiązań niepieniężnych jakakolwiek możliwość jej miarkowania de lege lata jest praktycznie wykluczona. Warto jednak rozważyć przynajmniej czysto hipotetycznie możliwość zastosowania tej zasady jako podstawy miarkowania opłat

\footnotetext{
${ }^{4}$ Zob. np. wyrok SN z 18 lipca 2000 r., III CZP 23/2000, OSP 2002, nr 3, poz. 36.
} 
komorniczych, gdyby mechanizm pobierania tej opłaty był odmienny. Kwestia wprowadzenia w ustawie możliwości miarkowania wysokości opłat egzekucyjnych była przedmiotem kontrowersji, w szczególności była i jest nadal kontestowana przez niektórych przynajmniej komorników. Nie można więc wykluczyć, że w przyszłości nastapią w tym zakresie kolejne zmiany ustawodawcze. Wówczas pytanie o stosowalność zasady zakazu nadużywania praw podmiotowych celem miarkowania wysokości opłat komorniczych może stać się w pełni aktualne. Warto więc rozważyć status prawny komornika, charakter prawny opłat, jakie pobiera, oraz rodzaj uprawnienia komornika do środków finansowych pobieranych tytułem tych opłat.

III. Kwestia dopuszczalności stosowania przynajmniej niektórych naczelnych zasad prawa prywatnego w całym systemie prawnym jest przedmiotem rozważań doktryny i judykatury zarówno w Polsce, jak i za granica. W szczególności pojawia się pytanie, czy możliwe jest stosowanie zasad prawa prywatnego na gruncie prawa publicznego w drodze analogii albo czy możliwe jest ich stosowanie w wyniku przyjęcia twierdzenia, że zasady te aczkolwiek wypracowane w nauce prawa cywilnego, sa naczelnymi zasadami całego syste$\mathrm{mu}$ prawnego. Powyższe pytania wiążą się z jeszcze szerszym zagadnieniem, a mianowicie relacją między prawem prywatnym a publicznym.

Jak wiadomo, system prawa publicznego co do zasady jest w przeciwieństwie do prawa prywatnego systemem $\mathrm{w}$ dużo większym stopniu zamkniętym. W nauce prawa prywatnego ze znacznie większą otwartością podchodzi się do zagadnień źródeł prawa, roli naczelnych zasad prawnych nie zawsze wyraźnie wysłowionych w przepisach czy też miejsca słuszności w systemie prawnym. W konsekwencji stosowanie w prawie publicznym naczelnych zasad wypracowanych na gruncie cywilistycznym jest mocno kontrowersyjne i natrafia na silną opozycję. Z drugiej strony w nauce niejednokrotnie wyrażano twierdzenie, że prawo prywatne, jako bardziej dojrzałe i lepiej ukształtowane, jest tzw. prawem powszechnym, a w konsekwencji zasady wypracowane na gruncie prawa prywatnego niejako przenikaja cały system prawny ${ }^{5}$.

Dla przykładu w doktrynie i judykaturze niemieckiej już w okresie międzywojennym XX w. uznano, że zasada zakazu nadużycia prawa podmiotowego jest naczelna zasadą całego niemieckiego systemu prawnego. Jej znaczenie wykracza więc poza tradycyjnie rozumiane prawo prywatne, dlatego też powinna być respektowana także na gruncie prawa publicznego ${ }^{6}$. Ponadto

${ }^{5} \mathrm{Na}$ temat koncepcji prawa cywilnego jako tzw. prawa powszechnego zob. A. de Laubadere, J.C. Venezia, Y. Gaudemet, Traité de droit administrative, t. 1, Paris. 1994, s. 29 i n. W prawie niemieckim wiele miejsca temu zagadnieniu poświęcił H. de Wall, Die Anwendbarkeit privatrechtlicher Vorschriften im Verwaltungsrecht, Tübingen 1999, już s. 1 i n. Na temat zasad prawa cywilnego będących również zasadami całego systemu prawnego zob. również H. Maurer, Allgemeines Verwaltungsrecht, München 1999, § 2, pkt 28 i n.; D. Ehlers, w: H. U. Erichsen (red.), Allgemeines Verwaltungsrecht, Berlin, New-York, 1998, § 2, pkt 68.

${ }^{6}$ Zob. A. Szpunar, Nadużycie prawa podmiotowego, Kraków 1947, s. 32 i n.; R. Szczepaniak, Nadużycie prawa do postugiwania się forma osoby prawnej, Toruń 2009, s. 82, s. 85 i n. Warto tutaj zwrócić uwagę przede wszystkim na monografię Ch. Pestalozza, „Formenmißbrauch” des Staates. Zu Figur und Folgen des „Rechtsmißbrauch" und ihrer Anwendung auf staatliches Ver- 
w nauce francuskiej i orzecznictwie tamtejszej Rady Stanu, ale także w doktrynie niemieckiej do naczelnych zasad prawa administracyjnego zalicza się m.in. tak oczywiste skądinąd dla każdego cywilisty zasady, jak zasada zakazu wzbogacenia się bez podstawy prawnej kosztem innej osoby czy zasadę, zgodnie z którą milczenie podmiotu (w tym wypadku organu administracyjnego) uważa się za decyzję odmowna, chyba że przepis szczególny stanowi inaczej7. We francuskiej nauce i orzecznictwie prawa administracyjnego istnieje także konstrukcja détournement de pouvoir, która wykazuje wiele podobieństw do cywilistycznej koncepcji zakazu nadużycia prawa podmiotowego. Chodzi o sytuację, gdy władza publiczna wykonuje swoje ustawowe kompetencje, ale w sposób sprzeczny z celem, dla osiągnięcia którego te kompetencje zostały jej przyznane $^{8}$. We francuskiej doktrynie prawa administracyjnego rozważa się także wprost kwestię stosowalności w prawie publicznym konstrukcji nadużycia prawa (abus de droit) ${ }^{9}$.

Polski SN wyraził niedawno pogląd, iż niektóre zasady prawa cywilnego mają rangę „podstawowych zasad porządku prawnego, wspólnych dla całego systemu prawa"10. W orzeczeniu tym do takich zasad zaliczył zasadę ochrony wierzycieli przed krzywdzącym działaniem dłużnika, a w szczególności zasadę, że interesy osoby, która uzyskała nieodpłatnie korzyść majątkowa, czyli bez jakiegokolwiek ekwiwalentnego świadczenia z jej strony, muszą ustapić przed interesami osoby, która w wyniku takiego przysporzenia doznała uszczerbku. W konsekwencji SN nie zawahał się zastosować, przynajmniej w drodze analogii, przepisów Kodeksu cywilnego regulujących tzw. skargę pauliańską do zobowiązań podatkowych, a ściśle mówiąc, do relacji podatnik-fiskus. Charakterystyczne jest, że SN nie zawahał się wyciagnaćc z tych zasad wnioski korzystne dla fiskusa (Skarbu Państwa) pozostającego w relacjach prawnych z obywatelem. W doktrynie natomiast można natrafić na pogląd, że w przypadku braku regulacji trybu domagania się zwrotu przez podmiot prawa publicznego świadczenia publicznoprawnego (chodziło o niewykorzystana dotację z budżetu jednostki samorządu terytorialnego) od podmiotu prywatnego można zastosować cywilnoprawną konstrukcję roszczenia o zwrot bezpodstawnego wzbogacenia (zwrot świadczenia nienależnego) z art. 405 i n. k.c. ${ }^{11}$, jako wyrażająca naczelną zasadę całego systemu prawnego, że nikt nie może się bezpodstawnie wzbogacić kosztem innej osoby. Wyrażano także pogląd, że przepisy Kodeksu cywilnego regulujące zasady i przesłanki od-

\footnotetext{
halten, München 1973, która kompleksowo analizuje stosowanie naczelnej zasady zakazu nadużywania praw podmiotowych w odniesieniu do najróżniejszych przejawów aktywności podmiotów sektora publicznego.

${ }^{7}$ Zob. A. de Laubadere, op. cit. s. 587 i 591; H. de Wall, op. cit., s. 60.

8 A. de Laubadere, op. cit., s. 498-499.

${ }_{9}^{9}$ Ibidem, s. 593-594; R. Goy, L'abus du droit en droit administratif français, „Revue du droit public et de la science politique en France et à l'étranger" 78, 1962, s. 5.

${ }^{10}$ Wyrok SN z 1 czerwca 2011 r., II CSK 513/10. Zob. także wyrok SN z 13 maja 2005 r., I CK 677/04, „Prawo Bankowe” 2005, nr 9, s. 10; wyrok SN z 28 października 2010 r., OSNC-ZD 2011, nr 1, poz. 23.

${ }_{11}$ Zob. T. Dembowska-Romanowska, Komentarz do prawa budżetowego państwa $i$ samorzqdu terytorialnego wraz z częściq ogólna prawa finansowego, Warszawa 1995, s. 75-77.
} 
powiedzialności odszkodowawczej również mają charakter takich naczelnych zasad przenikajacych cały system prawny ${ }^{12}$.

Niejako wbrew tendencji zarysowanej w powyższym orzeczeniu i poglądach wypowiadanych w doktrynie SN wypowiedział się w wyroku z 23 października 2006 r., że w prawie publicznym zasada zakazująca nadużycia prawa podmiotowego nie może być zastosowana. Zasada ta ma bowiem charakter cywilistyczny. Rygory prawa publicznego (w tym wypadku chodziło o przepisy emerytalno-rentowe) nie mogą być łagodzone konstrukcją nadużycia prawa podmiotowego przewidziana w art. 5 k.c. lub art. 8 k.p. ${ }^{13} \mathrm{~W}$ sprawie tej toczył się spór między osobą fizyczną i Zakładem Ubezpieczeń Społecznych o prawo do wcześniejszej emerytury ze względu na wykonywanie pracy w szczególnych warunkach. Ponadto, jak podkreślił SN, art. 5 k.c. i wyrażone w nim zasady współżycia społecznego nie moga być uznane za wystarczajaccą materialnoprawną podstawę świadczeń emerytalno-rentowych ${ }^{14}$.

IV. Wydaje się jednak, że zasada zakazująca nadużywania praw podmiotowych ma wszelkie cechy pozwalajace dostrzec w niej naczelną zasadę całego systemu prawnego, wykraczajacca poza prawo prywatne. Jak zostało wyżej wskazane, jej potencjał został już wiele lat temu dostrzeżony w nauce i judykaturze innych państw europejskich. Stosowanie tej zasady stanowi bowiem swoisty mechanizm wprowadzenia słuszności do porządku prawnego. Innymi słowy, zasada ta daje sędziom możliwość kreatywnego usuwania najbardziej skrajnych kolizji pomiędzy słusznością a litera prawa. Zresztą w polskiej literaturze można natrafić na twierdzenie, że zasada ta wykorzystywana jest zbyt rzadko, gdy tymczasem mogłaby być ona przydatna do rozwiązywania szeregu problemów stanowiacych wyzwania dla współczesnych prawników ${ }^{15}$.

Nie znaczy to oczywiście, że zastosowanie tej zasady na gruncie prawa publicznego oznaczać ma stosowanie art. 5 k.c. Sens tej zasady daleko wykracza bowiem poza przepis art. 5 k.c. Jak zauważa Sławomira Wronkowska, „zasady prawa nie sa "stosowane" tak, jak inne normy danego systemu prawnego. Realizowanie stanów rzeczy, które one wyznaczaja, dokonuje się

12 Zob. E. Łętowska, W zwiazku z odpowiedzialnościa za szkody wyrzadzone funkcjonowaniem administracji, w: Z. Rybicki, M. Gromadzka-Grzegorzewska, M. Wyrzykowski (red.), Zbiór studiów z zakresu nauk administracyjnych, Warszawa 1978, s. 59-60; J. Parchomiuk, w: System prawa administracyjnego, t. 12, Warszawa 2010, s. 12-13.

${ }^{13}$ Wyrok SN (Izba Pracy, Ubezpieczeń Społecznych i Spraw Publicznych) z 23 października 2006 r., I UK 128/06.

${ }^{14}$ W wyroku z 7 lutego 2007 r., II SA/Wr 481/06 WSA we Wrocławiu (niepublik.) orzekł, że „w postępowaniu administracyjnym nie ma podstaw prawnych do stosowania zasad prawa przyjętych w prawie cywilnym w tym [...] zasady współżycia społecznego". Z kolei w wyroku z 22 września 1983 r., SA/Wr 367/83, ONSA 1983, nr 2, poz. 75, NSA stwierdził, że ,art. 5 k.c. wytycza granice, w jakich osoba uprawniona może czynić użytek z przysługującego jej prawa; ze względu jednak na swą przynależność do systemu prawa cywilnego klauzula zgodności z zasadami współżycia społecznego nie może być stosowana w ocenie uprawnień lub obowiązków powstających w obszarze normowanym przepisami prawa administracyjnego bądź finansowego, w których nie występuje jej odpowiednik”. Zob. Z. Duniewska, w: System prawa administracyjnego, t. 1 , red. R. Hauser, Z. Niewiadomski, A. Wróbel, Warszawa 2010, s. 168.

15 Zob. T. Justyński, Nadużycie prawa w polskim prawie cywilnym, Kraków 2000, s. 153. 
poprzez inne normy tego systemu: przez tworzenie norm o odpowiedniej treści, odpowiednią interpretację i stosowanie norm nie będących zasadami prawa, wreszcie przez odpowiednie wykonywanie swoich praw"16.

Częściowym przynajmniej potwierdzeniem takiego poglądu jest uzasadnienie wyroku TK z 20 listopada 2012 r., w którym orzekł, że kompetencja sądu w zakresie miarkowania opłaty egzekucyjnej wprowadzona przepisami ustawy o komornikach nie jest sprzeczna z Konstytucja ${ }^{17}$. Co prawda w wyroku tym TK badał wcześniejszy stan prawny ${ }^{18}$, jednak istota wyroku sprowadzała się do oceny konstytucyjności sędziowskiego miarkowania owej opłaty. Trybunał w ustnym uzasadnieniu wyroku podniósł argument, że sądowe miarkowanie opłaty egzekucyjnej znajduje zastosowanie w sytuacjach wyjątkowych i ma na celu przeciwdziałanie nadużyciom prawa (sic! - podkreślenie R.S.) ${ }^{19}$. Identyczne sformułowanie, a więc odwołanie do konstrukcji nadużycia prawa znalazło się w pisemnym uzasadnieniu tego wyroku ${ }^{20}$. Tak więc zdaniem TK nałożenie przez komornika w postanowieniu opłaty egzekucyjnej według stawek ustawowych może być zakwalifikowane jako przejaw nadużycia prawa, zwłaszcza wówczas, gdy wysokość tej opłaty jest niewspółmiernie wysoka w stosunku do nakładu pracy komornika. Jak widać, TK nie ma wątpliwości, że także na gruncie prawa publicznego do nadużycia prawa może dochodzić oraz że przeciwdziałać mu może sędziowskie miarkowanie. Niezwykle istotne jest również to, że w świetle wyroku TK z 20 listopada 2012 r. zasada zakazująca nadużywania praw podmiotowych urasta do rangi jednej z zasad konstytucyjnych. Przy takim założeniu stosowaniu tej zasady nie stoi na przeszkodzie nawet przekonanie, że prawo publiczne jest systemem prawa zamkniętego ${ }^{21}$.

Trybunał nie podzielił argumentów skarżącego komornika, zdaniem którego możliwość sądowego miarkowania w oparciu o stosunkowo niejasno określone podstawy nie da się pogodzić z zasadami demokratycznego państwa prawnego, gdyż eliminuje pewność prawną. Trybunał przypomniał, że użycie przez ustawodawcę zwrotów niedookreślonych jest tradycyjną technika prawodawczą dająca systemowi prawnemu niezbędną elastyczność. Ponadto użycie przez ustawodawcę takich zwrotów niedookreślonych nie jest równoznaczne z arbitralnością rozstrzygnięcia, zwłaszcza że orzeczenie w przedmiocie miarkowania wydaje niezawisły sąd, a jego rozstrzygnięcie podlega kontroli instancyjnej, którą może zainicjować sam komornik.

${ }^{16}$ Zob. S. Wronkowska, w: A. Redelbach, S. Wronkowska, Z. Ziębiński, Zarys teorii państwa i prawa, Warszawa 1994, s. 226.

${ }_{17}$ SK 34/09.

${ }^{18}$ Chodziło o art. 49 ust. 2 oraz art. 49 ust. 1 zd. 2 ustawy o komornikach w brzmieniu nadanym przez art. 1 pkt 19 ustawy z 24 września 2004 r. o zmianie ustawy o komornikach sądowych i egzekucji oraz o zmianie ustawy - Kodeks postępowania cywilnego Dz. U. 2004, Nr 236, poz. 2356.

${ }^{19}$ Zob. Komunikat prasowy po rozprawie dotyczącej wysokości kosztów egzekucji komorniczej, http://www.trybunal.gov.pl/Rozprawy/2012/sk_34_09.htm.

${ }^{20}$ OTK ZU 2012, nr 10A, poz. 122.

${ }^{21}$ Zob. na temat koncepcji zamkniętego i otwartego systemu źródeł prawa: J. Zimmermann, Prawo administracyjne, Warszawa 2010, s. 49-51. 
Oczywiście obrona dłużnika żądającego miarkowania z powołaniem na zasadę zakazująca nadużywania praw podmiotowych musiałaby de lege lata przybrać formy przewidziane prawem procesowym. Na postanowienie komornika w przedmiocie ustalenia kosztów egzekucji służy skarga do sądu rejonowego na mocy art. 767 § 1 k.p.c. W szczególności przed niewspółmiernie wysoką opłatą egzekucyjną dłużnik mógłby się bronić, podnosząc w skardze zarzut naruszenia zasady zakazującej nadużycie praw podmiotowych. O naruszeniu tej zasady można by mówić wtedy, gdyby wysokość opłaty była nieadekwatna do nakładu pracy komornika, a ponadto za jej obniżeniem przemawiałaby wyjątkowo trudna sytuacja majątkowa i rodzinna dłużnika. Jak jednak słusznie wiele lat temu zauważył Alfred Ohanowicz, przesłanek nadużycia prawa podmiotowego nie da się z góry zegzemplifikować ${ }^{22}$. Dlatego też SN trafnie podkreśla, że dla zastosowania zasady zakazującej nadużycie prawa konieczna jest ocena całokształtu szczególnych okoliczności danego wypadku w ścisłym powiązaniu nadużycia prawa z konkretnym stanem faktycznym ${ }^{23}$.

Ważną okolicznością przemawiającą za stosowaniem konstrukcji nadużycia prawa podmiotowego jako instrumentu miarkowania opłat komorniczych byłby też fakt, iż w rozpatrywanym wypadku konstrukcja ta służyłaby jedynie do obrony przed żądaniem komornika uiszczenia opłaty w określonej wysokości. Powszechnie przyjmuje się w literaturze, że konstrukcja ta jest właśnie środkiem obrony, nie zaś samodzielna podstawa podnoszenia roszczeń ${ }^{24}$. W konsekwencji chodzi tutaj o zupełnie inny przypadek, niż ten, który rozpatrywał SN w wyżej wskazanym wyroku z 23 października 2006 r. W tamtej sprawie z konstrukcji tej skarżący wywodził prawo do emerytury.

Sąd, dokonując owej oceny całokształtu szczególnych okoliczności danego przypadku, nie powinien także abstrahować od specyfiki statusu prawnego komornika.

Jak wyjaśnił TK w uzasadnieniu wyroku z 18 listopada 2003 r. ${ }^{25}$ : „opłata egzekucyjna ustalona jest normatywnie w sposób niezwiązany z kosztami konkretnego postępowania egzekucyjnego. Inaczej mówiąc - ustawa nie zakłada, że każde postępowanie egzekucyjne ma przynosić komornikowi »dochód" ani nawet, że każde postępowanie egzekucyjne będzie się »bilansować«, tj. komornik otrzyma dokładnie tyle, ile wynosiły jego wydatki w tym postępowaniu. Oznacza to, że nie jest również wykluczone obciążenie komornika pewnymi kosztami, skoro bowiem zgodnie z konstrukcją opłaty jako "ryczałtowego" zwrotu kosztów i wynagrodzenia komornika dopuszczalne jest, aby komornik otrzymał kwotę wyższą niż jego wydatki, to możliwa jest również sytuacja odwrotna, polegająca na braku należytego zwrotu kosztów".

Nie można więc wykluczyć i takiej sytuacji, że w konkretnym przypadku opłata egzekucyjna i inne składniki pobieranych przez niego kosztów egzekucji nie będą wyrównywały kosztów dokonania określonych czynności, a pomimo tego komornik ustawowo będzie zobowiązany ich dokonać. W konsekwencji

\footnotetext{
${ }^{22}$ Glosa do orzeczenia SN z 11 września 1961 r., I CR 693/61, OSP 1962, poz. 290.

23 Wyrok SN z 11 grudnia 1994 r., II CRN 127/94, Lex, nr 82293.

${ }^{24}$ Zob. na ten temat R. Szczepaniak, Nadużycie..., s. 154 i n.

${ }^{25}$ K 5/2002, OTK ZU 2003, nr 9, poz. 98.
} 
jedno postępowanie egzekucyjne może być dla komornika źródłem relatywnie wysokich korzyści majątkowych, natomiast inne będzie z jego punktu widzenia deficytowe. Sąd tę specyfikę statusu komornika musiałby wziąć pod uwagę i ze szczególną ostrożnością tylko w wyjątkowych przypadkach uznać, że wysokość danej opłaty jest nie do pogodzenia z poczuciem słuszności i naczelna zasadą zakazu nadużycia praw podmiotowych ${ }^{26}$.

Na postanowienie sądu rejonowego w przedmiocie rozpatrzenia skargi dłużnika służy zażalenie zarówno temu dłużnikowi, jak i komornikowi (art. 770 k.p.c.). W konsekwencji istniejąca kontrola instancyjna zabezpiecza przed ewentualną arbitralnością rozstrzygnięcia sądu rejonowego. Ponadto, idąc tropem rozumowania TK, należy stwierdzić, że możliwość wydania rozstrzygnięcia w wyjątkowych wypadkach w oparciu o oceny związane ze stosowaniem naczelnej zasady zakazu nadużycia prawa podmiotowego nie może być traktowana jako wyraz arbitralności, lecz jako zapewnienie systemowi prawnemu wymaganej elastyczności celem stworzenia możliwości pogodzenia tzw. litery prawa z powszechnym poczuciem słuszności.

V. Autor zdaje sobie sprawę, że przeciwko zaprezentowanym wywodom może pojawić się silna opozycja. Może być podniesiony zarzut, że obecnie opłaty komornicze w egzekucji zobowiązań niepieniężnych mają wybitnie sztywny charakter. W szczególności art. 51 ustawy o komornikach sądowych i egzekucji wskazuje stałe stawki tych opłat i nie wprowadza przynajmniej wyraźnie możliwości ustalenia przez komornika wysokości opłaty w innej kwocie. W stanie prawnym, który rozpatrywał TK w wyroku z 20 listopada 2012 r. art. 49 ust. $1 \mathrm{zd}$. 2 upoważniał komornika i zobowiazzywał go zarazem do ustalenia wysokości opłaty egzekucyjnej związanej z egzekucją zobowiązań pieniężnych w wysokości „odpowiedniej do poniesionych przez komornika wydatków, nakładu jego pracy oraz wartości wyegzekwowanej części świadczenia zgłoszonego do egzekucji”.

W konsekwencji może się pojawić zarzut, iż trudno w rozpatrywanym przypadku mówić o nadużyciu prawa podmiotowego, skoro komornicy nie zostali ustawowo wyraźnie upoważnieni do modyfikowania wysokości tej opłaty, a w takim razie nałożenie w postanowieniu o kosztach egzekucji obowiązku na dłużnika uiszczenia kwot odpowiadających wysokości opłat egzekucyjnych w stałej kwocie wskazanej w art. 51 ustawy jest nie tyle ich prawem, ile obowiąziem. Być może przeciwnicy zaproponowanego stanowiska powołają się także na treść art. 7 Konstytucji, który stanowi, iż organy władzy publicznej, a do takich przecież zalicza się komornik, działają na podstawie i w granicach prawa. W konsekwencji musi on nakładać opłaty w wysokości określonej w przepisach.

Wydaje się jednak, że takie spojrzenie na kwestię opłat egzekucyjnych byłoby zbytnim spłyceniem całego problemu i cechowałoby się przesadnym for-

${ }^{26}$ Nie zapominajmy jednak, że na mocy art. 41 ust. 1 ustawy o komornikach sądowych i egzekucji komornik może zażądać od strony czy innego uczestnika postępowania zaliczki na pokrycie wydatków wnioskowanej czynności; od zapłaty tej zaliczki komornik może uzależnić dokonanie czynności. 
malizmem. Nie można abstrahować od specyficznego statusu komornika w całym systemie prawa, który sprawia, iż uchwycenie natury prawnej tej funkcji staje się zadaniem złożonym. Wykonuje on czynności egzekucyjne na własny rachunek, a pobierane opłaty stanowia jego przychód. Nie odprowadza ich przecież nawet w części, pomijając konieczność płacenia podatków, do budżetu państwa czy kasy innej jednostki sektora finansów publicznych. Dlatego też wszelkie zasady dotyczące wysokości i poboru opłat egzekucyjnych sami komornicy traktuja jako dotyczące bezpośrednio ich osobistych interesów prawnych i podmiotowych praw majątkowych przyznanych w ustawie, czego dowodzi chociażby skarga kasacyjna jednego z komorników, dająca impuls do wydania przez TK wskazanego wyżej wyroku z 20 listopada 2012 r. Status prawny komornika jest swoistą hybrydą prawną. Jest on funkcjonariuszem publicznym, używającym okragłej pieczęci z godłem Rzeczypospolitej Polskiej. Bezsprzecznie jest też organem orzekającym. Wydaje on bowiem orzeczenia, tj. postanowienia $\mathrm{w}$ ramach sądowego postępowania egzekucyjnego (np. art. 768 k.p.c., art. 770 (1) k.p.c.). Na postanowienia te przysługuje szczególny środek zaskarżenia do sądu, jakim jest skarga (art. 767 § 1 k.p.c.). Pomimo tego swoje ustawowe kompetencje i obowiazki wykonuje na własny rachunek. Opłaty, jakie pobiera, zalicza się zazwyczaj do opłat publicznoprawnych, ale jednocześnie stanowią one jego przychód jako osoby fizycznej, a wszelkie ustawowe ograniczenia ich poboru czy możliwość ich miarkowania są przez komorników odbierane jako zamach na ich konstytucyjnie chronione prawa podmiotowe, o czym świadcza przypadki wnoszonych przez komorników skarg konstytucyjnych czy też wystapienia do TK organizacji zrzeszających komorników ${ }^{27}$. Ta hybrydowość statusu prawnego komornika przypomina nieco sytuację prawna notariusza. W jednym i drugim przypadku możemy mówić o swoistej prywatyzacji zadań publicznych. Jak wiadomo, od początku lat dziewięćdziesiątych XX w. byliśmy świadkami wielu zjawisk stanowiących przejawy szeroko pojętej prywatyzacji zadań publicznych. Nie zawsze jednak w ślad za tymi procesami szła kompleksowa, wszechstronna analiza prawna towarzyszaccych tym procesom zdarzeń ${ }^{28}$.

Trybunał Konstytucyjny dał już wyraz temu, że hybrydowy status prawny komornika rodzi problemy, na rozwiązanie których polska judykatura nie do końca jest przygotowana. Wydając wyrok z 30 kwietnia 2012 r..$^{29}$, TK musiał odpowiedzieć na zagadnienie wstępne, czy skarga konstytucyjna wniesiona przez kolejnego komornika, w której domagał się on stwierdzenia niekonstytucyjności przepisów zezwalających na sądowe miarkowanie opłat egzekucyjnych, jest dopuszczalna. Trybunał ostatecznie odpowiedział na to pytanie twierdząco, aczkolwiek dochodzi do tego wniosku po wyraźnych wahaniach i z pewnymi oporami. Po pierwsze, TK podkreślał bowiem kilkakrotnie w uzasadnieniu, że komornik sądowy jest „monokratycznym, państwowym organem

${ }^{27}$ Zob. postanowienie TK z 18 listopada 2003 r., k 5/2002, OTK ZU 2003, nr 9A, poz. 104; wyrok TK z 30 kwietnia 2012 r., SK 4/2010, OTK ZU 2012, nr 4A, poz. 42.

${ }^{28} \mathrm{Na}$ temat zjawiska prywatyzacji zadań publicznych na przykładzie notariatu zob. S. Biernat, Prywatyzacja zadań publicznych. Problematyka prawna, Warszawa 1994, s. 89.

${ }^{29}$ SK 4/2010, OTK ZU 2012, nr 4A, poz. 42. 
egzekucyjnym", a między nim i wierzycielem oraz dłużnikiem zachodzą stosunki publicznoprawne. Jak dalej wywodził TK: „W związku z powyższym, jako podmiot pełniący funkcje władzy publicznej, komornik, co do zasady, nie jest legitymowany do składania skargi konstytucyjnej. Komornik nie może być jednocześnie organem państwa i osobą fizyczną dochodząca ochrony swoich konstytucyjnych praw”. Pomimo tych jednoznacznych twierdzen, TK kończy swój wywód konstatacja: „Ponieważ komornik jest organem samofinansującym się, to wynik prowadzonej działalności wpływa na jego osobiste prawa majątkowe. Z powyższych powodów Trybunał uznał za dopuszczalne rozpoznanie niniejszej skargi konstytucyjnej komornika ze względu na przedmiot sprawy" (zob. pkt 1.2 uzasadnienia). Jak się wyraził TK w uzasadnieniu wyroku, „dostrzega wielowymiarowość pozycji prawnej komornika” i dlatego „na zasadzie wyjątku" dopuścił skargę kasacyjną.

Końcowy wniosek Trybunału jest trafny. Z problematyka opłat egzekucyjnych, niezależnie od tego, jaki charakter prawny im przypiszemy, nierozerwalnie związane sa majątkowe prawa podmiotowe komornika, co Trybunał ostatecznie przyznaje, choć z oporami. W konsekwencji nie można kwestionować dopuszczalności wniesienia w tych sprawach skarg konstytucyjnych przez komornika, co oczywiście nie oznacza, iż są one zasadne.

Wywody TK tak naprawdę można sprowadzić do jednego zdania: opłata komornicza ma charakter publicznoprawny, ale zarazem komornik ma majątkowe prawo podmiotowe, by ją pobrać. Innymi słowy, mamy tutaj do czynienia ze zjawiskiem o eklektycznej naturze prawnej.

VI. Wydaje się, że trudności Trybunału w dokonaniu spójnej kwalifikacji statusu prawnego komornika wynikają ze zbytniego przywiązania się do tradycyjnego podziału na prawo publiczne i prywatne. Tymczasem komornika nie da się zakwalifikować w oparciu o ten podział wyłącznie do kategorii podmiotów prawa publicznego bez popadania w wewnętrzne sprzeczności. Ten tradycyjny podział nie jest bowiem do końca dostosowany do złożoności prawnej procesów, jakie określamy mianem prywatyzacji zadań publicznych. Wieloaspektowe zjawisko prywatyzacji zadań publicznych przyczynia się do powstawania takich hybrydowych instytucji prawnych, które wymykają się kwalifikacji opartej na tradycyjnym podziale porządku prawnego na publiczny i prywatny ${ }^{30}$. System prawny jest, albo przynajmniej powinien być, spójny. Spójności tej nie kwestionujemy, gdy uznajemy możliwość istnienia instytucji prawnych o mieszanym charakterze, w których zbiegają się różne kwestie prawne i różne relacje. Natomiast na pewno owej spójności systemu prawego zagraża bezrefleksyjne wytyczanie nieprzekraczalnych linii demarkacyjnych

${ }^{30} \mathrm{~W}$ nauce prawa administracyjnego ostatnimi laty pojawiło się np. pojęcie „nietypowe podmioty administrujące”. Chodzi tutaj głównie o państwowe jednostki organizacyjne wykorzystujące w swej działalności zarówno klasyczne formy administracyjnoprawne formy działania jak i formy typowe dla prawa cywilnego, zob. J. Jagielski, M. Wierzbowski, A. Wiktorowska, Nietypowe podmioty administrujace - kilka refleksji na tle organizacyjnych form wykonywania zadań publicznych, w: Podmioty administracji publicznej i prawne formy ich dziatania. Studia i materiaty $z$ konferencji naukowej poświęconej jubileuszowi 80-tych urodzin prof. E. Ochendowskiego, Toruń 15-16 listopada 2005 r., Toruń 2005. 
pomiędzy prawem publicznym i prywatnym. Zakreślanie takich granic nie powinno być wartością samą w sobie. Za każdym razem należy zadać pytanie, czemu wytyczanie takiego podziału służy i jakie rodzi konsekwencje praktycz$\mathrm{ne}^{31}$. W szczególności ten tradycyjny podział nie powinien stać na przeszkodzie stosowania w szeroko pojętym sektorze publicznym określonych zasad naczelnych tylko dlatego, że zostały wypracowane przez cywilistów. Właśnie spójność systemu prawnego wymaga, by pewne zasady traktować jako naczelne zasady całego porządku prawnego. Tymczasem ten tradycyjny podział niekiedy przypomina gorset przesadnie ograniczający efektywność systemu prawnego. Natomiast jednym z najistotniejszych przejawów owej efektywności jest zdolność do usuwania kolizji między tzw. litera prawa a słusznościa.

Dlatego też ujmowanie opłat egzekucyjnych jedynie od strony publicznoprawnej i niedostrzeganie tutaj podmiotowych praw majątkowych komorników stanowiłoby zubożenie dyskursu poświęconego jego statusowi prawnemu.

Przy czym chodzi tutaj o prawa podmiotowe w znaczeniu cywilnoprawnym. Uwaga ta jest o tyle zasadna, iż w doktrynie prawa administracyjnego występuje pojęcie „publicznych praw podmiotowych”, które, jak podkreślają administratywiści, nie jest kategorią tożsamą z cywilistycznym pojęciem „praw podmiotowych" 32 .

Ta hybrydowość zagadnień prawnych wiążących się ze statusem komornika sprawia, że pojawia się kolejne istotne zagadnienia, a mianowicie czy komornik jest władny w wydawanym przez siebie postanowieniu określić wysokość kosztów egzekucyjnej w niższej wysokości od tej, która wynika z treści art. 51 ustawy o komornikach sądowych i egzekucji. De lege lata taka możliwość nie istnieje, gdyż - jak zostało wyżej wskazane - kosztami orzeczonymi przez komornika w postanowieniu musi być obciążony dłużnik, by wyrównać wierzycielowi wydatki związane m.in. z zapłaconą już wcześniej przez niego opłatą egzekucyjna. Ewentualne obniżenie przez komornika kosztów, które powinien zapłacić dłużnik, wywołałoby ten skutek, że straciłaby na tym osoba trzecia, czyli wierzyciel.

Natomiast prowadząc czysto hipotetyczne rozważania, w przypadku gdyby mechanizm pobierania opłat egzekucyjnych był inny, skłaniałbym się do wniosku, że taka możliwość istniałaby. Co do zasady to komornik jest dysponentem kwot pobranych tytułem opłat egzekucyjnych. Kwoty te wzbogacaja go jako osobę fizyczną. Byłoby więc wysoce wątpliwe pod każdym względem stosowanie tutaj zapisanych w ustawie o finansach publicznych rygorystycznych zasad gospodarowania środkami publicznymi oraz argumentowanie, że pobranie przez komornika opłaty w niższej wysokości stanowi pogwałcenie art. 7 Konstytucji RP. Jeżeli sumienie i poczucie słuszności podpowiadałoby komornikowi, po uwzględnieniu nakładu jego pracy oraz trudnej sytuacji

${ }^{31}$ Zob. R. Szczepaniak, Sens i nonsens podziału na prawo publiczne i prywatne (na kanwie uchwaty SN), „Państwo i Prawo” 2013, z. 5, s. 38 i n.

${ }^{32}$ Zob. J. Zimmermann, Prawo administracyjne, Warszawa 2010, s. 274. Na temat publicznych praw podmiotowych zob. także P. Przybysz, w: M. Wierzbowski (red.), Prawo administracyjne, Warszawa 2011, s. 137-141. 
majątkowej i rodzinnej dłużnika, obniżenie tej kwoty, powinien on mieć taka możliwość.

Dlaczego mielibyśmy tworzyć niepotrzebną nikomu kolizję między litera prawa a słusznością? Tę pozorną w gruncie rzeczy kolizję można wyeliminować przez odpowiednią wykładnię przepisów inspirowaną naczelną zasadą zakazującą nadużywania praw podmiotowych.

VII. Aby wyprzedzić ewentualne kontrargumenty, należy jeszcze podnieść, że zaprezentowane wywody nie prowadzą bynajmniej do zakwestionowania konstytutywnych specyficznych cech danin publicznych, w tym zwłaszcza podatków. Na pewno nie jest tak, że na podobnej zasadzie można by kwestionować wysokość podatków i innych podobnych danin publicznych. Jak zostało wyżej przedstawione, to wyjątkowy sui generis status prawny komornika zainspirował do podjęcia powyższych rozważań. Celem autora jest zwrócenie uwagi, że podział na prawo prywatne i publiczne nie powinien stanowić samodzielnej wartości, tym bardziej że, jak dotychczas, nie udało się wypracować precyzyjnych kryteriów zakwalifikowania danych instytucji prawnych do prawa publicznego czy też prywatnego. Ten niejednokrotnie sztuczny podział nie może prowadzić do osłabienia efektywności systemu prawnego przejawiajacej się m.in. w usuwaniu rozdźwięku między tzw. literą prawa i słusznością.

VIII. Jak zostało wyżej wskazane, powyższe rozważania w znacznej części miały charakter hipotetyczny. W przypadku bowiem egzekucji zobowiazań pieniężnych ustawodawca wyraźnie przewidział możliwość miarkowania wysokości opłat, natomiast uregulowany w prawie obowiązującym sposób pobierania opłat $\mathrm{w}$ przypadku egzekucji zobowiązań niepieniężnych de lege lata uniemożliwia ich miarkowanie w oparciu o konstrukcję nadużycia prawa. Niemniej wyjątkowy, hybrydowy status prawny komornika inspiruje do podjęcia rozważań, które daleko wykraczają poza problematykę kosztów postępowania egzekucyjnego.

dr hab. Rafat Szczepaniak

Uniwersytet im. Adama Mickiewicza w Poznaniu

rafalsz@amu.edu.pl

THE ISSUE OF INDIVIDUAL RIGHTS AT THE BORDERLINE BETWEEN PRIVATE AND PUBLIC LAW. CONSIDERATIONS DE LEGE FERENDA ON THE EXAMPLE OF THE FEES PAYABLE TO THE BAILIFF

Summary

The author analyses the issue of admissibility of the application in the public sector of some legal institutions and principles developed in civil law. He focuses his considerations on the example of the fees charged by bailiffs collecting debt in the course of the enforcement of a court judgment. In Poland the impossibility of adjusting the charges levied by the bailiff from the debtor in connection with the enforcement of non-monetary obligations is widely criticised. The author expresses a view that such adjustment is not possible de lege lata even if the use of the principle 
prohibiting the abuse of rights with regard to these charges has been allowed. Neither a difficult financial situation nor a difficult family situation of the debtor allows to adjust such charges under current binding law. The inadmissibility of such measures is derived from the express provisions governing the procedure for levying the fee (i.e. it is charged in advance). If not for these rules, the author believes, it would be possible to adjust the fees based on the principle prohibiting the abuse of individual rights. The author believes that the division into public and private law itself is not an autonomous value. The bottom line is that the legal system allows to eliminate a collision between so-called the letter of the law and a common perception of what is fair. 
Copyright of Journal of Law, Economics and Sociology is the property of Faculty of Law and Administration of Adam Mickiewicz University in Poznan and its content may not be copied or emailed to multiple sites or posted to a listserv without the copyright holder's express written permission. However, users may print, download, or email articles for individual use.

Właścicielem praw autorskich do „Ruchu Prawniczego, Ekonomicznego i Socjologicznego” jest Wydział Prawa i Administracji Uniwersytetu im. Adama Mickiewicza w Poznaniu. Zawartość czasopisma nie może być kopiowana, przesyłana do innych stron internetowych bądź zamieszczana na blogach bez pisemnej zgody wydawcy. Niemniej artykuły można drukować, kopiować lub przesyłać w formie elektronicznej na własny użytek. 